\title{
Feasibility of Intraoperative Parathyroid Hormone Monitoring in Minimally Invasive Surgery
}

\author{
최소 침습적 수술을 위한 술중 부갑상선 호르몬 측정 알고리즘의 제안 \\ 김수진 · 윤주현 · 박 솔 · 고유진 · 이소정 · 정수연 · 김한수 \\ 이화여자대학교 의과대학 이비인후-두경부외과학교실
}

Soo Jin Kim, Ju Hyun Yun, Sohl Park, Yu Jin Go, So Jeong Lee, Soo Yeon Jung, and Han Su Kim

Department of Otorhinolaryngology-Head and Neck Surgery, College of Medicine, Ewha Womans University, Seoul, Korea

Received October 20,2020

Revised January 8, 2021

Accepted January 8, 2021

Address for correspondence

Han Su Kim, MD, PhD

Department of Otorhinolaryngology-

Head and Neck Surgery,

College of Medicine,

Ewha Womans University,

1071 Anyangcheon-ro,

Yangcheon-gu, Seoul 07985, Korea

Tel $+82-2-2650-5832$

Fax +82-2-2648-5604

E-mail sevent@ewha.ac.kr
Background and Objectives There has been a long debate on whether intraoperative parathyroid hormone (IOPTH) monitoring is mandatory or not in the excision of a single abnormal parathyroid gland. The aim of this study is to suggest a new criteron of IOPTH monitoring. Subjects and Method We retrospectively analyzed 31 patients who underwent parathyroidectomy from 2005 to 2019. Patients had IOPTH not measured and those with secondary hyperparathyroidism were excluded. IOPTH was measured preoperatively (EX00), at 10 minutes (EX10) and 20 minutes (EX20) after the excision and analyzed. We determined the surgery as a 'successful excision of lesion (SEOUL)' when it met the following criteria: criterion 1) the level of EX10 or EX20 decreased under the upper normal or under upper limit of parathyroid hormone (65 pg/mL); criterion 2) EX20 decreased below 50\% of EX00 and less than $195 \mathrm{pg} /$ $\mathrm{mL}$ (3 times the upper normal limit); criterion 3) multiglandular disease.

Results Twenty-five patients among 31 patients were included this study (M:F=8:17). Twenty-two patients were suspected of single lesion and three patients of multiple lesions on preoperative images $\left({ }^{99 \mathrm{~m}} \mathrm{Tc}\right.$-sestamibi scan, neck CT, and PET-CT). IOPTH of EX00, EX10, and EX20 were $488.92 \pm 658.74,121.36 \pm 134.73$, and $92.44 \pm 111.55 \mathrm{pg} / \mathrm{mL}$, respectively. Sixty-four percent patients $(16 / 25)$ met the criterion 1 . Six patients $(24 \%)$ successfully excised a lesion meeting the criterion 2 . Three patients had multiglandular disease, meeting the criterion 3.

Conclusion Our new criteria suggest when we could stop the procedure. If the level of IOPTH does not meet the SEOUL criteria, it means that there might be more lesions.

Korean J Otorhinolaryngol-Head Neck Surg 2021;64(7):491-9

Key Words Intraoperative monitoring · Parathyroidectomy · Parathyroid hormone · Primary hyperparathyroidism.
서 론

1차성 부갑상선 기능항진증(primary hyperparathyroidism)의 궁극적인 치료는 병변의 외과적 제거가 유일한 방법 으로, 대표적인 수술법으로는 양측 경부 탐색술과 최소 침습

This is an Open Access article distributed under the terms of the Creative Commons Attribution Non-Commercial License (https://creativecommons.org/licenses/by-nc/4.0) which permits unrestricted non-commercial use, distribution, and reproduction in any medium, provided the original work is properly cited.
적 부갑상선절제술(minimally invasive parathyroidectomy) 이 있다. 양측 경부 탐색술은 환자에게 존재하는 모든 부갑상 선을 탐색하여 육안으로 확인한 후 술중 동결절편검사에서 비정상적 병변으로 확인이 되면 제거를 하는 방법으로, 모든 부갑상선을 확인하고 동결절편검사를 시행하는데 시간이 많 이 소요되며 반회후두신경 손상 등 합병증이 발생할 가능성 이 높고, 사람마다 부갑상선의 개수 및 위치에 차이가 있어 간혹 탐색이 어려운 제한점이 있다. 반면 최소 침습적 부갑상 
선절제술은 모든 부갑상선을 육안으로 확인하는 대신 수술 전에 시행한 부갑상선 국소화 검사를 통해 의심되는 위치의 병변만을 제거한 후 술중 부갑상선호르몬(parathyroid hormone, PTH) 혈중 농도(intraoperative PTH, IOPTH)를 측 정함으로써 비정상적 병변의 제거 여부를 확인한 후 수술을 종료하는 방법이다. 최소 침습적 부갑상선절제술의 경우 양 측 경부를 모두 탐색하지 않는다는 장점이 있으나, 모든 부갑 상선을 확인하지 않음으로 잔여 병변을 남길 가능성을 가지 고 있어, 이를 줄이고 수술의 성공률을 높이기 위해 다양한 알고리즘이 제안되어 왔다(Table 1). ${ }^{1,2)}$ 본 연구에서는 최소 침습적 부갑상선절제술 적용 시 수술 성공률을 높일 수 있는 보다 세분화된 알고리즘을 제안하고자 한다.

\section{대상 및 방법}

2005년 1월 2019년 12월까지 부갑상선 기능항진증으로 수술 받은 31명의 환자를 대상으로 하였다. 연령, 성별, 술전/ 후 PTH 농도 및 $\mathrm{Ca}$ 을 포함한 혈액검사, 술전 부갑상선 국소 화 검사, IOPTH 측정치, 술후 병리 결과, 술후 추적 관찰 기 간 등에 대해 의무기록을 후향적으로 분석하였다(IRB No.
EUMC 2020-09-016).

수술 전 부갑상선 국소화(localization)를 위한 영상 검사로 는 ${ }^{99 \mathrm{~m}} \mathrm{Tc}-\mathrm{sestamibi(MIBI)} \mathrm{scan,} \mathrm{경부} \mathrm{컴퓨터단층촬영,} \mathrm{경부}$ 초음파 등이 시행되었으며, 환자별 검사 방법의 종류, 각 검사 별 진단 민감도 및 특이도를 측정하였다.

$\mathrm{PTH}$ 의 측정은 기본적으로 1) 수술 시작 전(pre-incision) 또는 의심 병변 절제 직전(pre-excision), 2) 의심 병변 절제 후 10 분 경과 시(EX10), 3) 병변 절제 후 20분 경과 시(EX20) 에 말초 정맥에서 혈액을 채취하여 시행하였다. 다발성 병변 의 경우 마지막 병변을 제거한 이후 10 분/20분에 혈액을 채취 하였으며, 술중 PTH의 감소폭이 예상치에 미치지 못하는 일 부 환자에서는 술자의 판단에 의해 추가적인 측정을 시행하 였다. 수술 전 외래에서 측정한 PTH, pre-incision PTH 및 pre-excision PTH 중 최고값을 기준값(EX00)으로 하여 수 술 중 측정한 $\mathrm{EX} 10, \mathrm{EX} 20$ 와 비교하였다. 혈중 $\mathrm{PTH}$ 의 측정 은 immunochemiluminometric assay(ICMA, E170, cobase 801, Roche, Basel, Switzerland)를 이용하였다.

본 연구에서는 다음과 같은 경우 더 이상의 병변이 없다고 판단하여 수술을 종료하였다[successful excision of lesions (SEOUL) criteria](Fig. 1).

Table 1. Various criteria of IOPTH determination

\begin{tabular}{|c|c|}
\hline \multicolumn{2}{|r|}{ Protocols } \\
\hline (1) Miami criteria ${ }^{3)}$ & When EX10 $\leq 50 \%$ of EXO0, it means there is no more abnormal gland \\
\hline (2) Normal IOPTH at $10 \mathrm{~min}^{4}$ & When EX10 $\leq 50 \%$ of EXOO and EX $10 \leq 65 \mathrm{pg} / \mathrm{mL}$, it means there is no more abnormal gland \\
\hline (3) Normal IOPTH at $20 \mathrm{~min}^{5}$ ) & When EX20 $\leq 50 \%$ of EXOO and EX20 $\leq 65 \mathrm{pg} / \mathrm{mL}$, it means there is no more abnormal gland \\
\hline (4) Rome criteria, & $\begin{array}{l}\text { When 'EX } 20 \geq 50 \% \text { of EX00' and/or 'EX } 20 \geq 65 \mathrm{pg} / \mathrm{mL} \text { ' and/or 'EX20 > EX10+7.5 ng/L,' it means } \\
\text { there are persistent hyperfunctioning parathyroid tissue }\end{array}$ \\
\hline
\end{tabular}

IOPTH: intraoperative parathyroid hormone, EX00: the highest preincision or preexcision parathyroid hormone level, EX10: a 10-minute postexcision IOPTH level, EX20: a 20-minute postexcision IOPTH level

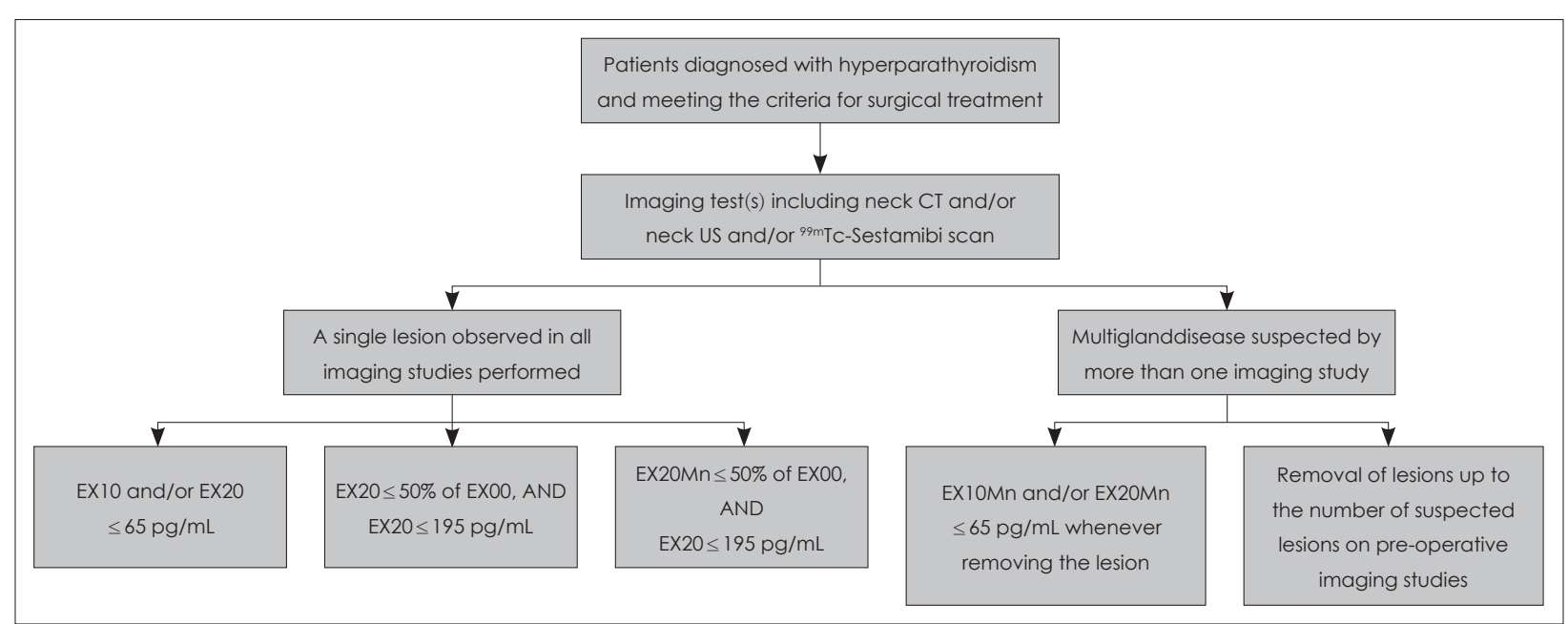

Fig. 1. SEOUL criteria. Detailed description about proposed SEOUL criteria which presented segmented criteria that were subdivided into groups of patients with suspected single lesion and multiple lesions. EX00: the highest preincision or preexcision parathyroid hormone level, EX10: a 10-minute postexcision IOPTH level, EX20: a 20-minute postexcision IOPTH level, IOPTH: intraoperative parathyroid hormone, EX10Mn: EX10 of n-th lesion, EX20Mn: EX20 of n-th lesion, SEOUL: successful excision of lesions. 
수술 전 국소화 검사에서 단일 병변인 경우

1) $\mathrm{EX10}$ 또는 $\mathrm{EX} 20$ 의 $\mathrm{PTH}$ 값이 정상 범위 $(15 \sim 65 \mathrm{pg} /$ $\mathrm{mL}$ ) 이내에 포함될 때, 또는 2) $\mathrm{EX} 20$ 이 $\mathrm{EX00}$ 의 50\% 이하이 면서 혈중 PTH 정상 상한 값의 3배수 $(195 \mathrm{pg} / \mathrm{mL})$ 이하일 때.

\section{수술 전 국소화 검사에서 다발성 병변인 경우}

1) 의심 병변을 제거 후 10 분 경과 $(\mathrm{EX} 10 \mathrm{Mn} ; \mathrm{n}$ 번째 병변 제거 후의 EX10) 또는 20 분 경과 $(\mathrm{EX} 20 \mathrm{Mn})$ 값이 정상 범위 $(15 \sim 65 \mathrm{pg} / \mathrm{mL})$ 이내에 포함될 때, 또는 2) 술전 국소화 검사 에서 발견된 의심 병변을 모두 제거했을 때.

술전 국소화 검사상 단일 병변이었으나 상기 조건에 해당 되지 않을 경우에는 추가적인 PTH 측정(EX30)을 시행하거 나 추가적인 병변의 존재 가능성을 염두에 두고 다른 부분을 탐색하였으며 추가 의심 병변이 발견되어 제거한 경우에는 criterion(1-2)을 동일하게 적용하였다. PTH 검사값의 통계 처리는 전체 환자군의 모수가 많지 않고 환자 간 값의 분산 이 심하여 평균절대편차를 이용하여 분석하였고, 알고리즘 간의 통계적 분석은 Kruskal-Wallis test를 이용하였다(R: a language and environment for statistical computing, 2020, $p<0.05)$.

\section{결 과}

\section{환자 구성 및 술전 검사 결과}

31 명 중 IOPTH를 criteria에 따라서 시행하지 않은 5명과, 2 차성 부갑상선 기능항진증 1 명을 제외한 1차성 부갑상선 기 능항진증 환자 25 명을 후향적으로 분석하였다. 환자들의 평 균( \pm 평균절대편차) 연령은 55.3( \pm 11.8$)$ 세였고, 남녀 비는 8:17 이었다. 동반된 질환으로는 고혈압(32\%)이 가장 많았고 당뇨 (20\%), 골다공증(16\%), 말기 신부전(12\%), 폐질환(12\%), 신장 결석(8\%), 갑상선질환(8\%), 관상동맥질환(8\%), 뇌졸중(8\%), 간질환(8\%), 고지혈증(8\%), 약물 알레르기(8\%), 하부 위장관 질환(8\%), 수신증(4\%), 요관결석(4\%), 알도스테론종(4\%), 신 경초종(4\%) 순이었다. 내원 당시 주증상은 전신무력감(28\%), 피로감(16\%), 구역감(12\%), 식욕부진(12\%), 변비(8\%), 손발저 림(8\%), 체중변화(8\%) 순이었고, 그 외 다뇨, 두통, 혈뇨, 근육 통, 옆구리 통증, 병적 골절, 심계항진 등의 증상이 있었으며, 무증상이 $36 \%$ 로 가장 많았다.

술전 평균( \pm 평균절대편차) 이온화 칼슘 수치는 $6.63( \pm 0.89)$ $\mathrm{mg} / \mathrm{dL}$ (정상 범위 4.6 5.4 mg/dL)이었고, 술전 혈청 칼슘 수 치는 $11.82( \pm 1.55) \mathrm{mg} / \mathrm{dL}$ (정상 범위 8.2 10.5 mg/dL)이었다. 술전 최고 혈중 PTH 농도(정상 범위 $15 \sim 65 \mathrm{pg} / \mathrm{mL}$ )는 68.07 2489.00 으로 평균 488.92( \pm 441.99$) \mathrm{pg} / \mathrm{mL}$ [단일 병변: 444.34
$( \pm 395.25) \mathrm{pg} / \mathrm{mL}$, 다발성 병변: 815.83( \pm 715.44$) \mathrm{pg} / \mathrm{mL}]$ 이 었으며, 정상 PTH 상한치인 $65 \mathrm{pg} / \mathrm{mL}$ 의 7.52( \pm 6.80$)$ 배[단일 병변: 6.84( \pm 6.08$)$ 배, 다발성 병변: $12.55( \pm 11.01)$ 배]였다.

\section{국소화를 위한 영상검사}

본 연구에서는 술전 병변의 국소화를 위해 MIBI scan, 경 부 전산화단층촬영, 경부 초음파검사 중 2 가지 이상을 시행 하였다. 25 명의 환자 중 9명(36\%)이 MIBI scan과 경부 컴퓨 터단층촬영을 시행받았고, 1 명(4\%)이 MIBI scan과 경부 초 음파검사를 시행받았으며, 1 명(4\%)이 경부 컴퓨터단층촬영과 경부 초음파검사를 시행받았다. 25 명의 환자 중 14 명 $(56 \%)$ 에 서는 3가지 검사를 모두 시행하였다(Fig. 2).

술전 국소화 검사에서 단일 병변 및 다발성 병변 환자 수 는 각각 22 명, 3 명이었고, 술후 최종적으로 확진된 단일 병변 및 다발성 병변의 환자 수도 각각 22 명 대 3 명으로 동일하였 으나, 술전 국소화 검사에서 단일병변으로 의심되던 1 명의 환 자가 술후 최종적으로는 다발성 병변으로 확진되었고, 술전 MIBI scan에서 다발성 병변이 의심되었던 1명의 환자가 술 후 단일 병변으로 진단되었다.

또한 수술 전 국소화 검사에서 검사 간 병변의 수가 일치하 지 않았던 환자는 7명으로, 술후 최종 단일 병변으로 진단된 환자가 5명, 다발성 병변으로 진단된 환자가 2명이었다(Tables 2 and 3). 단일 병변으로 최종 진단된 환자 5 명 중 4 명은 술전 국소화 검사에서 0 개 또는 1 개로 검사들 간에 불일치 소견이 있었고, 1 명에서는 MIBI scan 검사에서는 2 개의 의심 병변이 관찰되었으나, 경부 전산화촬영 및 경부 초음파에서는 1 개의 의심 병변이 관찰되었다(Table 2*). 술후 다발성 병변으로 최

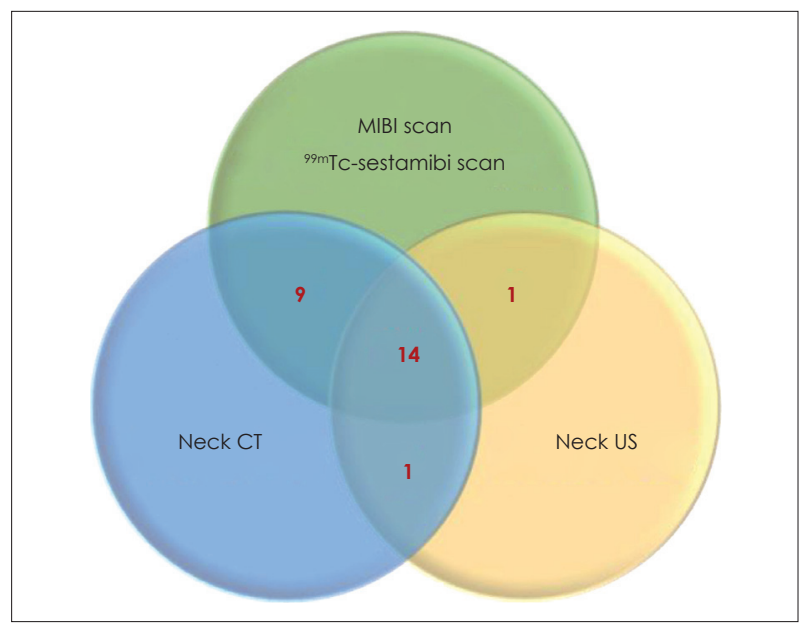

Fig. 2. Modalities of imaging tests for preoperative localization. Nine patients had both a MIBI scan and a neck CT. One patient had a MIBI scan and a neck US. One patient had a neck CT and a neck US, and 14 patients had all of three tests. MIBI: ${ }^{99 m} \mathrm{Tc}$-sestamibi, US: ultrasonography. 
종 진단된 환자 2명에서는 술전 검사상 단일 병변 소견을 보 인 검사는 없었으나 검사들 간 병변의 추정 개수가 일치하지 않았다(Table $2^{* *}$ ). 이 경우 MIBI scan에서의 병변의 개수

Table 2. Results of preoperative localization studies in the number of lesions

\begin{tabular}{|c|c|c|c|c|}
\hline \multicolumn{3}{|c|}{ Preoperative studies } & \multirow{2}{*}{$\begin{array}{c}\text { No. of } \\
\text { patients }\end{array}$} & \multirow{2}{*}{$\begin{array}{l}\text { Postoperatively } \\
\text { confirmed } \\
\text { number of lesions }\end{array}$} \\
\hline MIBI scan & Neck CT & Neck US & & \\
\hline 1 & 1 & - & 5 & 1 \\
\hline 0 & 1 & - & $1^{*}$ & 1 \\
\hline 0 & 0 & - & $1^{*}$ & 1 \\
\hline 0 & 1 & 1 & $2^{*}$ & 1 \\
\hline 1 & - & 1 & 1 & 1 \\
\hline- & 1 & 1 & 1 & 1 \\
\hline 1 & 1 & 1 & 10 & 1 \\
\hline 2 & 1 & 1 & $1^{*}$ & 1 \\
\hline 3 & 2 & - & $1^{* *}$ & 3 \\
\hline 3 & 4 & 4 & $1^{* *}$ & 3 \\
\hline 1 & 1 & - & $1^{* * *}$ & 3 \\
\hline
\end{tabular}

*patients with inconsistency among the preoperative localization studies (single gland disease), **patients with inconsistency among the preoperative localization studies (multiglandular disease), ***patient with inconsistency between preoperative and postoperative results. MIBI: ${ }^{99 \mathrm{~m} T C-s e s t a m i b i, ~ U S: ~ u l t r a s o n o g-~}$ raphy
와 위치가 술중 소견과 일치하였다. 그 외, 술전 시행한 MIBI scan과 경부 전산화단층촬영상 단일 병변으로 소견이 일치하 였으나 수술 결과 다발성 병변으로 최종 진단되었던 환자가 1 명이었다(Table $2^{* * *}$ ).

MIBI scan은 민감도 $83 \%$, 정확도 $75 \%$ 였고, 경부 전산화단 층촬영은 민감도 $96 \%$, 정확도 $83 \%$ 였으며, 경부 초음파는 민 감도 $100 \%$, 정확도 $93 \%$ 였다(Table 3, Fig. 3).

\section{병 리}

$\mathrm{IOPTH}$ 를 시행한 일차성 부갑상선 기능항진증 25 명의 환 자 중 최종 진단을 기준으로 단일 병변의 환자가 22 명, 다발 성 병변의 환자는 3 명이었다. 이 중 부갑상선 선종이 19 명 (76\%)으로 가장 많았고, 부갑상선 증식증이 4 명 $(16 \%)$, 부갑 상선 낭종과 부갑상선 암종이 각각 1 명(4\%)이었다. 최종 다발 성 병변으로 진단된 경우 3 명의 환자 모두에서 3 개의 병변이 발견되었고, 이 중 1 명은 부갑상선 선종, 2 명은 부갑상선 증식 증이었다.

\section{IOPTH}

술전 국소화 검사상 단일 병변으로 추정되었던 환자 군에 서, EX10 또는 EX20가 혈중 PTH 농도의 정상 범위로 회복

Table 3. Comparison between preoperative localization studies

\begin{tabular}{|c|c|c|c|c|c|c|c|c|c|}
\hline & \multicolumn{3}{|c|}{ MIBI scan (24) } & \multicolumn{3}{|c|}{ Neck CT (24) } & \multicolumn{3}{|c|}{ Neck US (16) } \\
\hline & Single & Multiple & Negative & Single & Multiple & Negative & Single & Multiple & Negative \\
\hline Single gland disease & 16 & 1 & 4 & 20 & 0 & 1 & 15 & 0 & 0 \\
\hline Multiglandular disease & 1 & 2 & 0 & 1 & 2 & 0 & 0 & 1 & 0 \\
\hline
\end{tabular}

MIBI: ${ }^{99 m}$ TC-sestamibi, US: ultrasonography

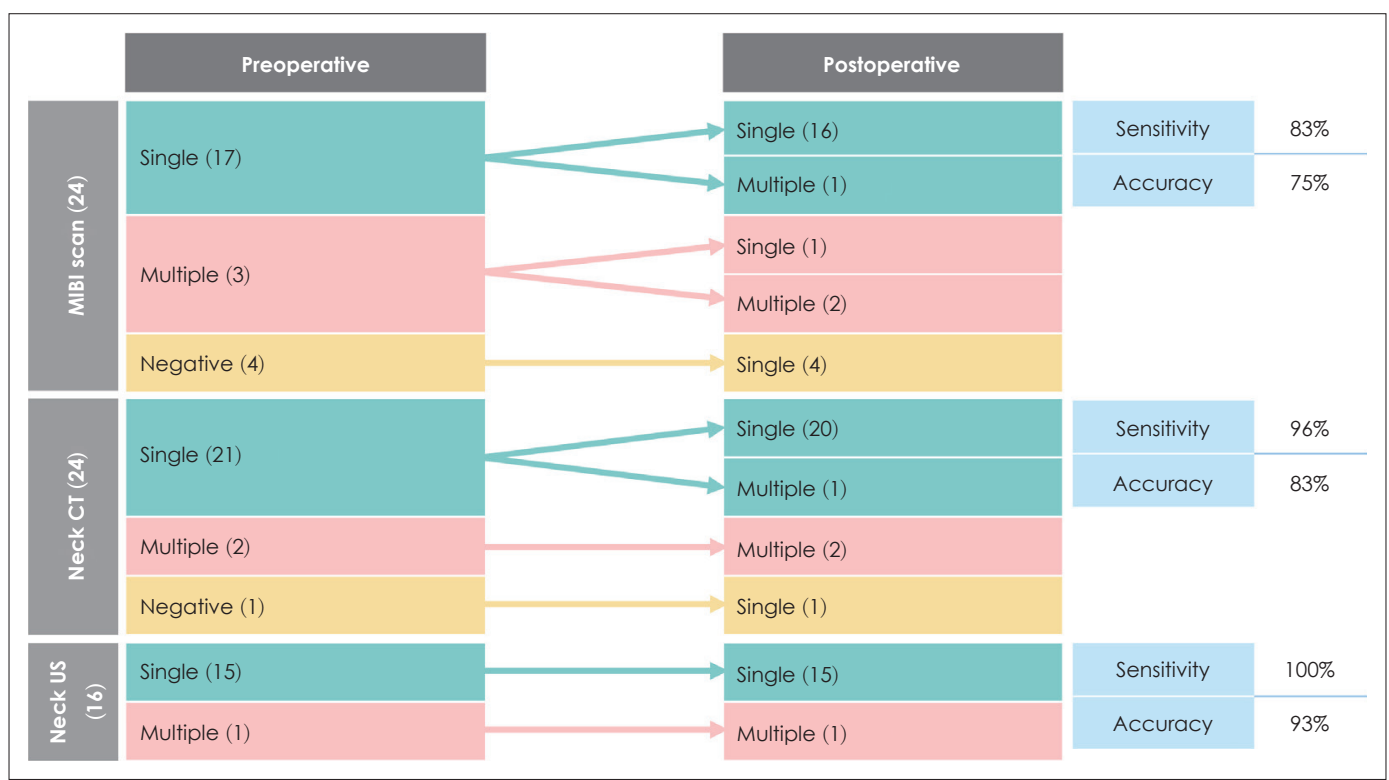

Fig. 3. The sensitivity and specificity of the imaging localization test. There is an inconsistency among 3 preoperative localization tests. MIBI: ${ }^{99 m}$ TC-sestamibi, US: ultrasonography. 
되어 SEOUL criterion(1-1)에 해당하는 환자가 16명(73\%), $\mathrm{EX} 20$ 가 EX00의 $50 \%$ 이하이면서 혈중 PTH 정상 상한값의 3 배수 이하가 되어 SEOUL criterion(1-2)에 해당하는 환자 가 5명(23\%)이었다. 술전 국소화 검사 소견상 단일 병변으로 생각되었던 환자 중 1명은 SEOUL criteria(1-1) 또는 (1-2)에 해당되지 않아 추가적인 병변의 존재 가능성을 염두에 두고 수술을 진행하였으며, 추가 병변을 발견하여 제거하였고, 제 거 후 20 분에 측정한 PTH 값( $\left(\mathrm{EX} 20 \mathrm{M}_{2}\right)$ 이 $\mathrm{EX00}$ 의 $50 \%$ 이 하이면서 PTH 정상 상한값이 3배수 이하가 되었을 때 수술 을 종료하였다. 환자는 술후 추적 관찰 2 개월에 정상 혈청 칼 슘 수치 $(7 \mathrm{mg} / \mathrm{dL})$ 를 유지하였다.

술전 시행한 국소화 검사 중 1 개 이상의 검사에서 다발성 병변으로 의심되었던 환자는 3 명이었고, 이 중 2 명은 3 번째 병변 제거 후 10 분 경과 시의 혈중 PTH 농도( $\left.\mathrm{EX} 10 \mathrm{M}_{3}\right)$ 가 혈 중 PTH 정상 범위로 회복되어 SEOUL criterion(2-1)에 해 당하였다. 나머지 1명은 SEOUL criterion(2-2)에 따라 술전 시행한 영상검사상 의심되는 병변의 위치에서 추가적인 조직 을 제거 후 수술을 종료하였으나, 절제한 두 개의 조직이 각각 부갑상선 선종과 갑상선 조직으로 판정되어 최종적으로는 단 일 병변으로 진단되었고 추적 관찰 8.5 개월에 정상 혈청 칼 슘 수치 $(8.6 \mathrm{mg} / \mathrm{dL})$ 을 유지하였다.

술후 병리 결과에 따른 최종 진단을 기준으로 단일 병변 환자 군의 경우 IOPTH는, EX10이 $101.26 \mathrm{pg} / \mathrm{mL}( \pm 88.51)$, $\mathrm{EX} 20$ 가 $65.37 \mathrm{pg} / \mathrm{mL}( \pm 51.21)$ 로, $\mathrm{EX00}$ 과 비교했을 때 EX10 이 $69.59 \%( \pm 16.53)$ 감소했고, $\mathrm{EX} 20$ 이 $79.97 \%( \pm 16.20)$ 감소 했다. 이를 PTH 농도의 정상 상한치와 비교하면, EX10이 1.56 배 $( \pm 1.36), \mathrm{EX} 20$ 이 0.87배 $( \pm 0.76)$ 였다. 술후 병리 결과에 따른 최종 진단을 기준으로 다발성 병변 환자군의 IOPTH는 EX10이 $54.75 \mathrm{pg} / \mathrm{mL}( \pm 31.77), \mathrm{EX} 20$ 가 $16.14 \mathrm{pg} / \mathrm{mL}( \pm 2.66)$ 였다.

술후 단일 병변으로 확진된 환자 군에서 EX00와 EX10의 차이가 EX00의 $50 \%$ 미만이었던 환자는 4명(18\%)이었고, 이 중 3명(14\%)은 $\mathrm{EX00}$ 과 $\mathrm{EX} 20$ 의 차이 또한 $\mathrm{EX00}$ 의 $50 \%$ 미 만이었다. 단일 병변의 환자 군에서 $\mathrm{EX10}$ 이 정상범위로 회복 되지 못한 환자는 8명(36\%)이었고, 이 중 6명(27\%)은 EX20 도 정상범위로 회복되지 못했다. 이 6 명의 EX20의 정상 PTH 농도 상한값에 대한 비율은 2.25( \pm 0.81$)$ 였고, EX20의 편차가 6명의 평균절대편차인 0.81 보다 큰 경우는 1 명으로 해당 환자 의 EX20의 정상 PTH 농도 상한값에 대한 비율이 4.12였다.

다발성 병변으로 확진된 환자 3명 중, 술전 국소화 검사에 서도 다발성 병변으로 의심되었던 2 명의 경우, 술전 시행한 국소화 검사상 의심되는 병변의 개수가 검사 간 불일치하는 소견을 보였는데, 1 명은 MIBI scan상 3 개, 경부 컴퓨터단층
촬영 상 2 개의 병변이 의심되었고, 다른 1 명은 MIBI scan상 3 개, 경부 컴퓨터단층촬영과 경부 초음파검사상 각각 4 개의 병변이 의심되었다. 두 환자에서 의심되는 각 병변을 제거할 때마다 EX10, EX20을 측정하였고, 두 환자 모두 $\mathrm{EX}_{10 \mathrm{M}_{3}}$ 가 $\mathrm{EX00}$ 의 $50 \%$ 이상 감소하면서 정상 범위 이내로의 회복을 보 여 수술을 종료하였다.

다발성 병변으로 확진된 환자 3 명 중, 술전 국소화 검사에서 는 단일 병변으로 의심되었던 1명의 경우 EX10이 EX00으로 부터 50\% 이상의 감소율을 보였으나 EX00 값이 $1889 \mathrm{pg} / \mathrm{mL}$ 으로 매우 높았고, $50 \%$ 이상 감소한 EX10 값이 $492.2 \mathrm{pg} / \mathrm{mL}$, $\mathrm{EX} 20$ 값이 $488.1 \mathrm{pg} / \mathrm{mL}$ 로 EX20 값이 정상 상한치의 7.51배 에 달하면서 정상범위로 회복하지 못하였다. 이에 따라, 추가 적인 병변의 존재 가능성을 염두에 두고 수술을 진행한 결과

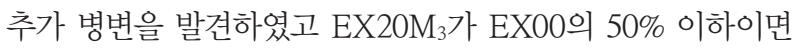
서 PTH 정상 상한값의 3 배수 이하가 되어 수술을 종료하였다.

\section{경 과}

수술 후 평균 추적 관찰 기간은 18.44 개월 $( \pm 18.25)$ 이었고, 4 명은 수술 후 추적 관찰을 하지 못하였다. 4명 중 3명은 내원 당시 무증상으로 건강검진상 우연히 발견된 고칼슘혈증 또는 부갑상선낭종으로, 1 명은 경부 종물로 내원하여 술후 무증상 으로 추적 진료를 받지 않은 것으로 사료된다. 25 명의 환자 중 다발성 병변을 가진 환자 1 명이 술후 손떨림과 저림 증상 을 호소하여 술후 10 일에 혈중 PTH 농도 및 혈청 칼슘 수치 를 측정하였고, 혈청 칼슘 수치는 정상범위보다 약간 낮은 정도의 수준 $(7.3 \mathrm{mg} / \mathrm{dL})$ 을 보였으나, PTH 농도가 상승 소견 (163.2 pg/mL)을 보였다. 이후 1개월 4개월에 혈청 칼슘 수치 를 1 개월, 5 개월에 PTH 추적 검사를 시행하였으며, 칼슘 수 치는 정상범위(1개월에 $8.5 \mathrm{mg} / \mathrm{dL}, 4$ 개월에 $8.9 \mathrm{mg} / \mathrm{dL}$ )였으 나 PTH 농도는 여전히 상승소견(1개월에 $174.4 \mathrm{pg} / \mathrm{mL}, 5$ 개 월에 $180.6 \mathrm{pg} / \mathrm{mL}$ )을 보여 경부 컴퓨터단층촬영과 $\mathrm{MIBI}$ scan을 시행하였으나 이상 소견은 없었다. 술후 1 회 이상의 추적 진료를 받은 21 명의 환자 중 추적 관찰 결과 재발한 예 는 없었다.

\section{알고리즘 간의 비교}

SEOUL criteria 및 기존 다른 연구에서 제시된 기준( $\mathrm{Ta}-$ ble 1)을 비교하여 민감도, 특이도, 양성예측도, 음성예측도, 정확도를 산출하였고(Table 4), 각각에 대한 진양성(true positive), 진음성(true negative), 위양성(false positive), 위음성 (false negative)을 산출하였다(Table 5). 진양성은 IOPTH 검 사에서 의심 병변을 모두 제거하였다고 판단하여 수술을 종 료한 후 수술 후 혈액검사 및 영상검사에서 정상이 된 경우 
Korean J Otorhinolaryngol-Head Neck Surg I 2021;64(7):491-9

Table 4. Comparison of SEOUL criteria with other protocols for using IOPTH monitoring

\begin{tabular}{|c|c|c|c|c|c|}
\hline Protocols & Sensitivity & Specificity & $\begin{array}{c}\text { Positive } \\
\text { predictive value }\end{array}$ & $\begin{array}{c}\text { Negative } \\
\text { predictive value }\end{array}$ & Accuracy \\
\hline SEOUL criteria & 96 & 100 & 100 & 50 & 96 \\
\hline Miami criteria ${ }^{3)}$ & 83 & 0 & 95 & 0 & 80 \\
\hline Normal IOPTH at $10 \mathrm{~min}^{4)}$ & 52 & 0 & 100 & 0 & 52 \\
\hline Normal IOPTH at $20 \mathrm{~min}^{5)}$ & 64 & 0 & 100 & 0 & 64 \\
\hline Rome criteria $^{5,6)}$ & 84 & 0 & 100 & 0 & 84 \\
\hline
\end{tabular}

Data are presented as percentage. SEOUL: successful excision of lesion, IOPTH: intraoperative parathyroid hormone

Table 5. Comparison among performances of SEOUL criteria and other protocols

\begin{tabular}{|c|c|c|c|c|}
\hline Protocols & $\begin{array}{c}\text { True } \\
\text { positive }\end{array}$ & $\begin{array}{c}\text { True } \\
\text { negative }\end{array}$ & $\begin{array}{c}\text { False } \\
\text { positive }\end{array}$ & $\begin{array}{c}\text { False } \\
\text { negative }\end{array}$ \\
\hline SEOUL criteria & $23(92)$ & $1(4)$ & $0(0)$ & $1(4)$ \\
\hline Miami criteria ${ }^{3)}$ & $20(80)$ & $0(0)$ & $1(4)$ & $4(16)$ \\
\hline Normal IOPTH at $10 \mathrm{~min}^{4)}$ & $13(52)$ & $0(0)$ & $0(0)$ & $12(48)$ \\
\hline Normal IOPTH at $20 \mathrm{~min}^{5)}$ & $16(64)$ & $0(0)$ & $0(0)$ & $9(36)$ \\
\hline Rome criteria ${ }^{5,6)}$ & $21(84)$ & $0(0)$ & $0(0)$ & $4(16)$ \\
\hline
\end{tabular}

Data are presented as $n$ (\%). SEOUL: successful excision of lesion, IOPTH: intraoperative parathyroid hormone

이다. 진음성은 IOPTH 수치상 잔여 병변의 존재가 의심되어 추가적 탐색술이 필요한 상황으로, 추가 탐색술로 추가 병변 을 절제하였거나, 수술 종료 후 검사에서 잔여 병변이 발견된 경우이다. 위양성은 IOPTH 수치에서 의심 병변을 모두 제거 한 것으로 판단하여 수술을 종료하였으나, 술후 환자의 혈액 검사 또는 영상검사에서 잔여 병변이 발견된 경우이다. 마지 막으로 위음성은 IOPTH 수치상 잔여 병변의 존재가 의심되 어 추가적인 탐색술이 필요한 상황이나, 추가 탐색술에서나 수술 종료 후 검사상 잔여 병변이 발견되지 않아 실제로는 모 든 병변이 제거된 경우이다.

SEOUL criteria의 경우 $96 \%$ 의 민감도와 정확도, $100 \%$ 의 특이도와 양성예측도, $50 \%$ 의 음성예측도를 가졌다. 그에 비해 protocol(1)(Miami criteria)의 경우에는 83\%의 민감도, $95 \%$ 의 양성예측도, $80 \%$ 의 정확도를 보였고, protocol(2)(normal $\mathrm{IOPTH}$ at $10 \mathrm{~min}$ )의 경우에는 $52 \%$ 의 민감도, $100 \%$ 의 양성 예측도, $52 \%$ 의 정확도를 보였으며, protocol(3)(normal IOPTH at $20 \mathrm{~min}$ )의 경우에는 $64 \%$ 의 민감도, $100 \%$ 의 양성예측도, $64 \%$ 의 정확도를, protocol(4)(Rome criteria)의 경우 $84 \%$ 의 민감도, $100 \%$ 의 양성예측도, $84 \%$ 의 정확도를 보였다. Proto$\operatorname{col}(1)$ (4)의 성공률이 각각 $80 \%, 52 \%, 64 \%, 84 \%$ 인 것에 비 해 SEOUL criteria의 성공률은 $96 \%$ 로 통계적으로 유의하 게 높았다.

\section{고 찰}

1 차성 부갑상선 기능항진증의 수술적 치료에 있어 술전 부
갑상선 국소화를 위한 영상학적 검사 및 $\mathrm{PTH}$ 측정 기술의 발달에 따라 최소 침습적 수술의 개념이 도입되었다. 최소한 의 피부절개, 수술 시간의 단축, 회복기간 및 재원 기간의 단 축, 합병증의 감소 등의 장점으로 인해 1 차성 부갑상선 기능 항진증의 수술에 있어 최소 침습적 수술의 선택이 일반화되 었고 이에 수술의 성공률을 높이기 위한 많은 연구가 이루어 져 왔다. ${ }^{1,2)}$ 최소 침습적 수술의 경우 술전 '영상검사'를 통해 병변을 국소화하고, 술중 병변이 완전히 제거될 경우 $\mathrm{PTH}$ 의 측정값이 충분히 감소할 것이라는 가정에 기반하여, IOPTH 측정값의 변화를 통해 의심되는 병변의 제거 여부를 추정하 고 수술의 종료 여부를 결정하게 된다. 즉, 최소 침습적 수술 의 성공은 술전 국소화 검사의 정확도 및 최적화된 IOPTH 알고리즘에 의해 영향을 받는다. 따라서 수술 성적의 향상을 위해 술전 병변의 국소화 방법의 검증-9) 및 IOPTH 측정과 관련하여 혈액채취 위치, 시기, 빈도, 측정된 PTH 값의 변화 추세에 따른 수술 종료 여부 결정을 위한 최적화된 알고리즘 이 다양하게 제시되어왔다. ${ }^{3-6,10,11)}$ 한편, 1 차성 부갑상선 기능 항진증의 원인이 단일 선종에 의한 경우가 높고, ${ }^{12)}$ 영상학적 검사의 발달로 술전 병변의 발견율이 높아짐에 따라 술전 국 소화 검사가 단일병변으로 일치하는 경우에는 IOPTH 측정 이 수술의 성공률에 미치는 영향이 적으므로, IOPTH 측정 없이 최소 침습적 수술을 시행하는 것에 대한 논의가 증가하 는 추세에 있다. ${ }^{13-16)}$ 그러나 다발병소에 관한 술전 개별 영상 검사의 위음성률이 높고 술전 국소화 검사에서 단일병변의 일치된 소견을 보이더라도 다발병소를 놓칠 가능성이 존재하 므로 IOPTH 측정을 배제하기는 어려운 것이 사실이다. $15,17,18)$

결과에서 보듯이 술전 국소화 영상검사들에는 민감도 및 특이도에 차이가 있다. 따라서 술전 병변을 국소화하는 데 있 어 단일검사보다는 여러 검사의 조합이 진단의 민감도를 높 일 수는 있겠으나, 여러 영상검사에서 단일병변의 일치된 소 견을 보이더라도 다발성 병변의 가능성은 여전히 존재하므로 (Table 1), 이를 보완할 수 있는 IOPTH의 측정 알고리즘이 있다면 IOPTH 측정은 충분히 유용하다고 할 수 있다. 또한 술전 국소화 검사상 다발성 병변이 의심되는 경우에도 실제 로는 단일 병변인 경우가 있으므로 술전 영상검사를 보완할 
방안 역시 필요함을 알 수 있다.

\section{제안된 $\mathrm{IOPTH}$ 측정 알고리즘의 특징}

본 연구에서는 술전 국소화 검사의 결과를 적극적으로 활 용하면서 동시에 IOPTH 측정을 이용하여 다발성 병변의 발 견 가능성을 높이고, 다발성 병변이 의심되는 환자에서의 적 절한 수술 종료 시점을 결정하기 위한 알고리즘을 제시하였 다. 즉, 술전 국소화 검사에서 단일 병변으로 소견이 일치하는 경우와 그렇지 않은 경우로 나누어 기준을 제시함으로써 술 전 국소화 검사의 결과를 최대한 활용하였고, 단일 병변 및 다발성 병변 의심 환자 군에서도 세분화된 기준을 제시하여 다발성 병변의 발견 가능성은 높이되 불필요한 탐색술의 시 행 가능성은 낮추고자 하였다. 이는 술전 국소화 검사에 비해 SEOUL criteria의 향상된 민감도와 정확도를 통해 확인할 수 있다(Table 4, Fig. 3). 또한 부갑상선의 경우 병변 제거 시 술자의 병변 조작에 의해 PTH 측정치가 증가할 가능성 및 호르몬의 반감기가 3 5분임을 고려하여 병변 제거 후 5 분, 10 분 경과 후보다는 10 분, 20 분 경과 후의 PTH 측정치를 사 용하였다. 기준이 되는 혈중 $\mathrm{PTH}$ 의 농도가 너무 높거나 오히 려 낮은 경우에 IOPTH 측정값 자체나 감소율이 기존 알고리 즘들에서 오류를 유발하는 원인이 되는 것에 착안하여 본 연 구에서는 PTH 농도의 정상 범위 상한치와의 비교과정을 추 가하여 수술 종료 시점을 결정하였다.

본 연구에서 제시한 SEOUL criteria를 적용했을 때의 수 술(from skin to skin)에 소요된 시간은, 갑상선절제술이나 중심경부림프절절제술을 부갑상선절제술과 함께 시행했거나 악성을 의심하여 동결절편검사를 같이 시행했던 환자들을 제 외한 12 명에서 평균 $52 \pm 15$ 분이 소요되었고, 동결절편검사만 추가로 함께 시행했던 5 명에서의 평균 $78 \pm 27$ 분과 비교할 때 동결절편검사에 소요되는 시간(약 25 분) 만큼의 차이를 보였 다. 술자의 숙련도에 따라 수술에 소요되는 시간은 달라질 수 있으나 본원의 경우 SEOUL criteria(2)에 해당하여 다발성 병변에 관한 탐색술을 시행하게 된 4명의 경우 평균 $163 \pm 31$ 분의 시간이 수술에 소요되었고, 양측 경부 탐색술에 소요되 는 시간이 이와 비슷하거나 그 이상의 시간이 소요될 것으로 가정한다면 단일 병변의 경우 최소 침습적 부갑상선절제술은 유의미한 수술 시간의 단축을 보였다고 할 수 있다. 본원에서 $\mathrm{PTH}$ 측정에 사용된 기기의 경우 검사에 걸리는 시간이 18 분 이고, 실제 PTH 측정에 소요된 시간은 평균 $21 \pm 4$ 분이나, 현 장 현시 검사 장비나 더욱 짧은 시간에 IOPTH 검사 결과를 보고하는 기기들의 등장으로 최소 침습적 부갑상선절제술에 소요되는 시간은 향후 더욱 단축 가능할 것이다. ${ }^{19)}$

\section{알고리즘 간의 비교}

술전 국소화 검사상 단일 병변으로 소견이 일치하였으나 술후 최종적으로 다발성 병변으로 확진된 환자의 경우 EX10 이 $\mathrm{EX00}$ 에 비해 $50 \%$ 이상 감소하였으나 기준이 되는 혈중 $\mathrm{PTH}$ 의 농도가 매우 높았기 때문에 $\mathrm{EX10}$ 이 $\mathrm{PTH}$ 정상 상한 치의 7.57배에 해당하였고, EX20 역시 7.51배로 높은 수치를 보여 SEOUL criteria, protocol(2) (4)의 경우 다발성 병변을 의심하여 추가 탐색이 필요하였다. 추가 탐색술의 결과 2 개를 추가로 더 제거하였고, 마지막 병변 제거 후 10 분 경과 시의 $\mathrm{PTH}$ 측정값이 PTH 정상 상한치의 3 배 이내로 감소하여 수 술을 종료하였으며, 술후 측정한 PTH 농도 및 칼슘 수치상 잔여 병변은 없는 것으로 판단하였다. 해당 환자의 경우 추가 2 개의 병변 제거 후 10 분 경과 시의 PHT 측정값이 정상 범위 를 상회하여 $\operatorname{protocol}(2)$ 에 의해서는 추가적인 탐색술의 가능 성이 있었으나 SEOUL criteria 및 protocol(3), (4)에 의해서 는 성공적인 발견 및 제거가 가능하였다.

술전 국소화 검사에서 병변의 갯수에 불일치를 보였던 단 일 병변 환자들 중 다발성 병변의 가능성을 보였던 한 명의 환자의 경우 $\mathrm{EX} 10$ 이 $\mathrm{EX00}$ 에 비해 $50 \%$ 이상 감소하여 protocol(1)에 의해서는 수술을 바로 종료할 수 있었으나 SEOUL criteria, protocol(2) (4)에 의해서는 바로 종료할 수 없었다. 그러나 술전 영상검사에서 의심되는 두 번째 병변의 위치가 국소화되어 있었으므로 완전한 탐색술을 피할 수 있었고, 해 당 위치에서 의심병변을 제거한 후 20 분 경과 PTH 수치가 정상화되어 SEOUL criteria, protocol(3), (4)에 의해서 수술 을 종료할 수 있었다.

술전 국소화 검사상 병변의 수가 일치하지 않았던 다발성 병변 2명의 경우 각 영상검사상 2 개 이상의 병변을 국소화하 였기 때문에 영상검사들 간에 위치가 일치하는 2 개 이상의 병변을 제거 후 각 protocol을 적용하였고, SEOUL criteria 및 모든 protocol에서 동일한 수의 병변 제거 후 수술을 종료 할 수 있었다.

각 protocol의 위양성률 및 위음성률을 비교하면, 25 명의 환자 중 병변의 완전한 제거 측면에서 protocol(1)을 적용할 경우에만 다발성 병변 환자 1 명에서 병변을 완전히 제거하지 않은 채 수술을 종료할 가능성이 있었고 나머지 protocol에 서는 술중 병변을 모두 제거할 수 있음을 의미하였다. 불필요 한 추가 병변 탐색술의 가능성에 있어서는, protocol(1)의 경 우 4 명의 단일 병변 환자에서, protocol(2)는 11명의 단일 병 변 환자와 1 명의 다발성 병변 환자에서, protocol(3)은 9 명의 단일 병변 환자에서, protocol(4)는 4명의 단일 병변 환자에 서 불필요한 추가 병변 탐색술을 시행할 가능성이 존재했다 (Table 5). 
이에 비해 SEOUL criteria이 보였던 96\%의 민감도와 정확 도, $100 \%$ 의 특이도와 양성예측도, $50 \%$ 의 음성예측도는 병 변을 완전히 제거하지 않은 채 수술을 종료하는 경우는 없으 나, 1 명의 단일 병변 환자가 불필요한 추가 병변 탐색술을 받 을 가능성이 있었음을 의미한다. 그러나 추가 병변 탐색술을 시행할 가능성이 있었던 실제 해당 환자의 경우 술전 영상 검 사 중 MIBI scan에서 추가 병변이 의심되는 소견이 있었기에, SEOUL criteria(1-2)에 의해 의심되는 위치에서 추가 절제 후 수술을 종료하였다. 추가 절제한 조직은 병리결과 갑상선 조직이었고 수술 다음날 혈중 PTH 농도는 정상화 되었으며, 추적 관찰 기간인 8.5 개월 동안 정장 수준의 혈중 $\mathrm{PTH}$ 농도 값과 혈청 칼슘 농도값을 유지하였다.

이와 같이, SEOUL criteria의 경우 $\operatorname{protocol}(1) \sim(4)$ 와 비교 할 때 가장 높은 성능을 보였고, protocol(4)의 경우 높은 민 감도, 양성예측도, 정확도를 보여 알고리즘의 성능면에서는 높은 편이었으나, 특히 EX00이 높지 않은 경우(77.41 \pm 12.06 $\mathrm{pg} / \mathrm{mL}), \mathrm{EX} 20$ 이 정상범위라 할지라도 기준값의 $50 \%$ 이하 로 감소하지 않아 SEOUL criteria에 비해 상대적으로 높은 위음성률(16\%)을 보였다. 반면 protocol(2)와 (3)의 경우에는 $\mathrm{EX00}$ 이 너무 높은 경우(각각 1058.73 $\pm 727.96,1141.58 \pm 759.94$ $\mathrm{pg} / \mathrm{mL}$ )에 EX10과 EX20이 정상범위로 감소하지 않았고, 반

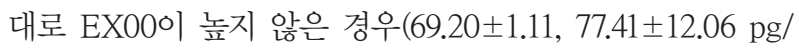
$\mathrm{mL}$ )에 기준값의 $50 \%$ 이하로 감소하지 않아 높은 위음성률

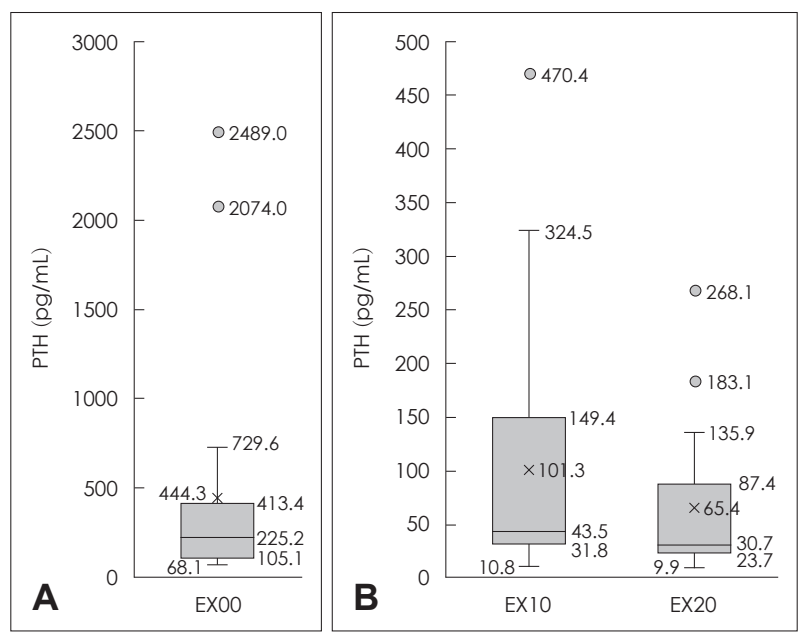

Fig. 4. PTH distribution for baseline (EX00), 10 minutes after the excision (EX10) and 20 minutes after the excision (EX20) (boxand-whisker plots display 25th, 50th, 75 th and interquartile range). For EX00, median=225.2, lower quartile=105.1, upper quartile= 413.4, minimum $=68.1$, maximum $=729.6$, minimum value in the data $=68.1$, maximum value in the data $=2489.0 \mathrm{pg} / \mathrm{mL}(\mathrm{A})$, for $E X 10$, median $=43.5$, lower quartile $=31.8$, upper quartile $=149.4$, minimum $=$ 10.8 , maximum $=324.5$, minimum value in the data $=10.8$, maximum value in the data $=470.4 \mathrm{pg} / \mathrm{mL}$, for $\mathrm{EX} 20$, median $=30.7$, lower quartile=23.7, upper quartile=87.4, minimum=9.9, maximum=135.9, minimum value in the data $=9.9$, maximum value in the data $=268.1$ $\mathrm{pg} / \mathrm{mL}(\mathrm{B})$.
(각각 $48 \%, 36 \%$ )을 보였다. 이는 본 연구에서와 같이 극단적 인 PTH 값이 존재(Fig. 4)하더라도 SEOUL criteria를 적용 할 경우 오류를 줄일 수 있음을 의미한다.

\section{한계점}

본 연구의 경우 $\mathrm{PTH}$ 값의 편차가 다양한 것에 비해 환자 수가 충분하지 않고 후향적 연구에 의한 한계가 존재한다. 이 에 향후 수술에 본 연구에 제시된 방법을 적용하여 치료 성 공률 검증에 관한 선행적 연구가 가능할 것으로 생각한다.

결론적으로, 술전 병변의 국소화에 있어 중요한 영상검사 들의 발달에 따라 술전 병변의 발견율 및 정확도가 높아지고 있어, $\mathrm{IOPTH}$ 측정의 알고리즘에 이를 적절히 활용할 경우 술중 다발성 병변의 발견 가능성을 높일 뿐 아니라 불필요한 탐색술의 가능성을 줄일 수 있을 것이다. 또한 기준이 되는 혈중 PTH의 농도가 너무 극단적인 경우를 위해 세분화된 알 고리즘을 적용함으로써 획일적인 알고리즘에 의한 오류를 감 소시킬 수 있을 것으로 생각한다.

\section{Acknowledgments}

None.

\section{Author Contribution}

Conceptualization: Soo Jin Kim, Ju Hyun Yun. Data curation: Soo Jin Kim, Yu Jin Go, So Jeong Lee. Formal analysis: Soo Jin Kim, Han Su Kim. Investigation: Soo Jin Kim, Han Su Kim. Methodology: Soo Jin Kim, Ju Hyun Yun, Han Su Kim. Project administration: Soo Yeon Jung, Han Su Kim. Resources: Soo Jin Kim, Han Su Kim. Software: Soo Jin Kim, Sohl Park. Supervision: Soo Yeon Jung, Han Su Kim. Validation: Soo Jin Kim, Han Su Kim. Visualization: Soo Jin Kim, Han Su Kim. Writing —original draft: Soo Jin Kim, Han Su Kim. Writing — review \& editing: Soo Jin Kim, Han Su Kim.

\section{ORCID}

Han Su Kim https://orcid.org/0000-0003-2239-0225

\section{REFERENCES}

1) Khan AA, Khatun Y, Walker A, Jimeno J, Hubbard JG. Role of intraoperative $\mathrm{PTH}$ monitoring and surgical approach in primary hyperparathyroidism. Ann Med Surg (Lond) 2015;4(3):301-5.

2) Singh Ospina NM, Rodriguez-Gutierrez R, Maraka S, Espinosa de Ycaza AE, Jasim S, Castaneda-Guarderas A, et al. Outcomes of parathyroidectomy in patients with primary hyperparathyroidism: A systematic review and meta-analysis. World J Surg 2016;40(10): 2359-77.

3) Carneiro DM, Solorzano CC, Nader MC, Ramirez M, Irvin GL 3rd. Comparison of intraoperative iPTH assay (QPTH) criteria in guiding parathyroidectomy: Which criterion is the most accurate? Surgery 2003;134(6):973-9; discussion 979-81.

4) Chiu B, Sturgeon C, Angelos P. Which intraoperative parathyroid hormone assay criterion best predicts operative success? A study of 352 consecutive patients. Arch Surg 2006;141(5):483-7; discussion 487-8.

5) Di Stasio E, Carrozza C, Pio Lombardi C, Raffaelli M, Traini E, 
Bellantone R, et al. Parathyroidectomy monitored by intra-operative PTH: The relevance of the 20 min end-point. Clin Biochem 2007; 40(9-10):595-603.

6) Lombardi CP, Raffaelli M, Traini E, Di Stasio E, Carrozza C, De Crea $\mathrm{C}$, et al. Intraoperative PTH monitoring during parathyroidectomy: The need for stricter criteria to detect multiglandular disease. Langenbecks Arch Surg 2008;393(5):639-45.

7) Arici C, Cheah WK, Ituarte PH, Morita E, Lynch TC, Siperstein AE, et al. Can localization studies be used to direct focused parathyroid operations? Surgery 2001;129(6):720-9.

8) Chang HS, Yoon JH, Chung WY, Park CS. Minimally invasive focused parathyroidectomy (MIFP). J Korean Surg Soc 2004;66(6): 467-71.

9) Vaid S, Pandelidis S. Minimally invasive parathyroidectomy: A community hospital experience. Arch Surg 2011;146(7):876-8.

10) Harrison BJ, Triponez F. Intraoperative adjuncts in surgery for primary hyperparathyroidism. Langenbecks Arch Surg 2009; 394(5):799-809.

11) Riss P, Kaczirek K, Heinz G, Bieglmayer C, Niederle B. A “defined baseline" in PTH monitoring increases surgical success in patients with multiple gland disease. Surgery 2007;142(3):398-404.

12) Purcell GP, Dirbas FM, Jeffrey RB, Lane MJ, Desser T, McDougall IR, et al. Parathyroid localization with high-resolution ultrasound and technetium Tc 99m sestamibi. Arch Surg 1999;134(8):824-8; discussion 828-30.
13) Lee SH, Hong SJ. Minimally invasive parathyroidectomy without an intraoperative i-PTH test for patients with primary hyperparathyroidism. J Korean Surg Soc 2008;75(1):9-14.

14) Mihai R, Palazzo FF, Gleeson FV, Sadler GP. Minimally invasive parathyroidectomy without intraoperative parathyroid hormone monitoring in patients with primary hyperparathyroidism. Br J Surg 2007;94(1):42-7.

15) Bergenfelz AO, Hellman P, Harrison B, Sitges-Serra A, Dralle H; European Society of Endocrine Surgeons. Positional statement of the European Society of Endocrine Surgeons (ESES) on modern techniques in pHPT surgery. Langenbecks Arch Surg 2009;394(5): $761-4$.

16) Sartori PV, Saibene AM, Leopaldi E, Boniardi M, Beretta E, Colombo $\mathrm{S}$, et al. Intraoperative parathyroid hormone testing in primary hyperparathyroidism surgery: Time for giving up? Eur Arch Otorhinolaryngol 2019;276(1):267-72.

17) Sebag F, Hubbard JG, Maweja S, Misso C, Tardivet L, Henry JF. Negative preoperative localization studies are highly predictive of multiglandular disease in sporadic primary hyperparathyroidism. Surgery 2003;134(6):1038-41; discussion 1041-2.

18) Palestro CJ, Tomas MB, Tronco GG. Radionuclide imaging of the parathyroid glands. Semin Nucl Med 2005;35(4):266-76.

19) Suh YJ, Kim SJ, Lee KE, Youn YK. Localization of parathyroid adenoma and minimally invasive parathyroidectomy: A review. Korean J Endocr Surg 2014;14(3):138-43. 